Egyptian Journal of Aquatic Biology \& Fisheries

Zoology Department, Faculty of Science,

Ain Shams University, Cairo, Egypt.

ISSN $1110-6131$

Vol. 23(4): 409 - 420 (2019)

www.ejabf.journals.ekb.eg

\title{
New recorded alein polydorid species (Polychaeta: Spionidae) from the Egyptian waters
}

\author{
Faiza Ali Abd Elnaby
}

National Institute of Oceanography and Fisheries, Alexandria, Egypt.

\section{ARTICLE INFO \\ Article History: \\ Received: Oct. 19, 2019 \\ Accepted: Oct. 27, 2019 \\ Online: Oct. 30, 2019}

Keywords:

Polychaeta

Spionidae

Alein species

El Max

Abu Qir

Gulf of Suez.

\begin{abstract}
Benthic samples were collected from Suez Gulf within the Project of Betro Gulf petrolum campany 2015; Anather coastal samples were collected from Aqaba and Suez Gulf as well as the Red Sea to study water quality, benthos and bacterial indicators for pollution 2010, Also samples were collected from rocky shore from El Max and Abu Qir stations (Alexandria) 2016. In the present study, 10 spionid species, genus: Polydora, Dipolydora, Boccardia and Pseudopolydora were reported. Six of them are new records to Egyptian waters. Polydora cornuta Bosc, 1802, Dipolydora socialis (Schmarda, 1861), Pseudopolydora paucibranchiata (Imajima \& Hartman, 1964) and D. armata (Langerhans, 1880) are considered alein species , Polydora websteri (Hartman in Loosanoff \& Engle, 1943) is considered as lessepsian migrant species, it is indo-pacific origin reported before in Red Sea and migrated through Suez Canal, and Dipolydora protuberata (Blake \& Kudenov, 1978 The importance of major setae of setiger 5 with its relation with boring and non boring activity for polydorid species are reported.
\end{abstract}

\section{INTRODUCTION}

Spionidae is one of more diverse family, some are harmfull for other aquatic mollusks, they are divided to boring species, and non-boring. The borer type Penetrate calcareous substrates, causing an economic loss of aquaculture manufacture and natural aquatic environment, such as damage, less growth rate, mortality of most edible mollusks, due to poisoning as a result of their production of hydrogen sulphide that may cause death (Radashevsky et. al., 2006), also they considered the first reason for diversity loss (Sato-Okoshi et. al. 1990 , 2008; Simon et. al, 2010; Mack et al. 2000; Miura 2007; Katsanevakis et al. 2014). Non boring type live in crevces of calcareous substrate and tubes (Blake and Evans 1973 ; Blake 1996 ; Sato-Okoshi 1999 ; Simon and Sato-Okoshi 2015). Polydorids as a general, are collected from different habitats, soft, mud and hard calcareous substraum (Blake 1996 ; Sato-Okoshi 1999\& 2000). Radashevsky \& Pankova (2006) and Sato-Okoshi \& Abe (2013), mentioned that there are no suffiicient specific information characters to help in the identification of polydora species. But some species have variable characters, such as pigmentation on the body and palps, special setae on setiger number five, pygedium shape; all these characters help to identify polydorids to species level (Teramoto et. al. 2013). Recently, molecular analyses used, make identification so easy (SatoOkoshi and Abe 2012 , 2013 ; Teramoto et. al., 2013). Thick branchial blood vessels or narrow vessels, strong palp or weak palp, the shape and the arrangment of the 
major spines of setiger 5 in one row or two are important to detect if it's type are boring species or non-boring species (Sato- Okoshi, 2000).

Five polydora species were reported before by Abd Elnaby (2005); Selim (1978, 1997 and 2006) and Mostafa (1992). They are: Pseudopolydora anntenata, Boccardia polybranchia, Polydora ciliata, Polydora giardi and Dipolydora caeca.

Polydora is the most important genus among alien polychaetes (Çinar, 2013). The present study deals with 6 new recorded polydora species to the Egyptian marine waters, four of them are considered alien species. Notes of description, added to descriptive Egyptian polychaetes, recording their distribution. This study considered as a new step to complete a catalogue contain Egyptian polychaetes, also focusing on alien polydorid species. In order to show the future change in the diversity of the area. examined samples are deposited in the Marine Reference collection Center, National Institute of Oceanography and Fisheries, Alexandria, Egypt.

\section{MATERIALS AND METHODS}

Benthic samples were collected from Suez Gulf within the Project of Betro Gulf petrolum campany 2015; Anather coastal samples were collected from Aqaba and Suez Gulf as well as the Red Sea to study water quality, benthos and bacterial indicators for pollution 2010, Also samples were collected from rocky shore from El Max and Abo Qir stations (Alexandria) 2016. (Figure 1). Benthic samples were collected by using van veen grab $(15 \times 15 \mathrm{~cm})$. In the laboratory samples were washed through $0.1 \mathrm{~mm}$ mesh sieve for small polychaetes and $0.5 \mathrm{~mm}$ for the rest of fauna, then fixed with a $10 \%$ formaldehyde solution, materials were sorted under a stereomicroscope, then identified to species level. The photographs of the special setae which present on setiger number five of polydora species were taken by a digital camera attached to stereo and compound microscopes.
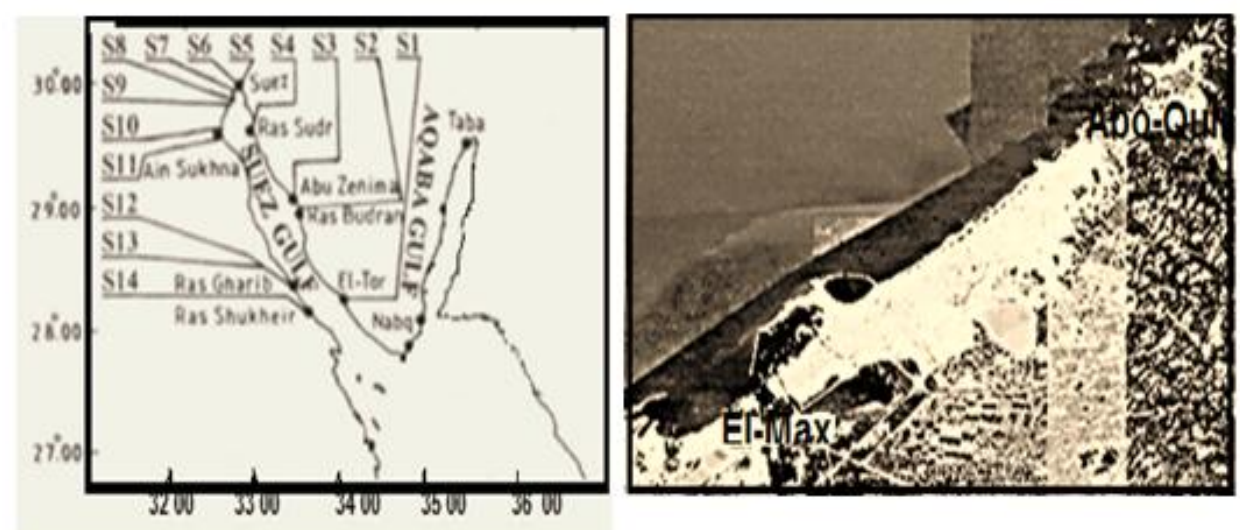

Fig. 1: Map showing the names and sampling locations for Suez Gulf, Abu-Qir\& El-Max

\section{RESULTS}

Boccardia polybranchia (Haswell, 1885), Dipolydora giardi (Mensil, 1896), Dipolydora caeca (Oersted, 1843) and Polydora ciliata (Johnston, 1838); were previously recorded by (Selim, 2006; Abd El-naby, 2005; and Hamdy, 2008). Added to this study, six new recorded polydoriod species; one of them reported before from Red Sea Polydora websteri (Hartman in Loosanoff \& Engle, 1943), Pseudopolydora paucibranchiata (Imajima \& Hartman, 1964) and Dipolydora armata, Dipolydora 
socialis, and Polydora cornuta are cosidered alien species and Dipolydora protuberata (Blake \& Kudenov, 1978).

Pseudopolydora paucibranchiata (Imajima \& Hartman, 1964).

Polydora paucibranchiata Okuda, 1937:231

Material examined: specimens were collected from Abu-Qir Bay, with mud and sandy mud respectivily.

Incomplete spesimen.Tube-building spionid polychaete. Prostomium anteriorly rounded, with four black eyes posteriorly with a caruncle reaching the third segment. Two long palps present. Chaetiger 1, bundle of notochaetae is absent, while the neuropodial lobes, with a small bundle of capillary are present. small parapodial lobes are present on chaetigers 2-4, but the lobes are rudimentary on chaetiger 5. Fifth chaetiger with modified chaetae in two rows: the inner row with 9 simple blunt chaetae; the outer row with 8 thick chaetae with slender curved tips and subdistal constrictions. From chaetiger 8 neuropodia with 10 hooded hooks. Gills from chaetiger 7 (Fig. 2). The species is here recorded for the first time for Egyptian waters. Remarks: All characters agrees with Sato-Okoshi (2000).

Distribution: Atlantic Ocean, Med. Sea, Indian Ocean and Pacific Ocean.
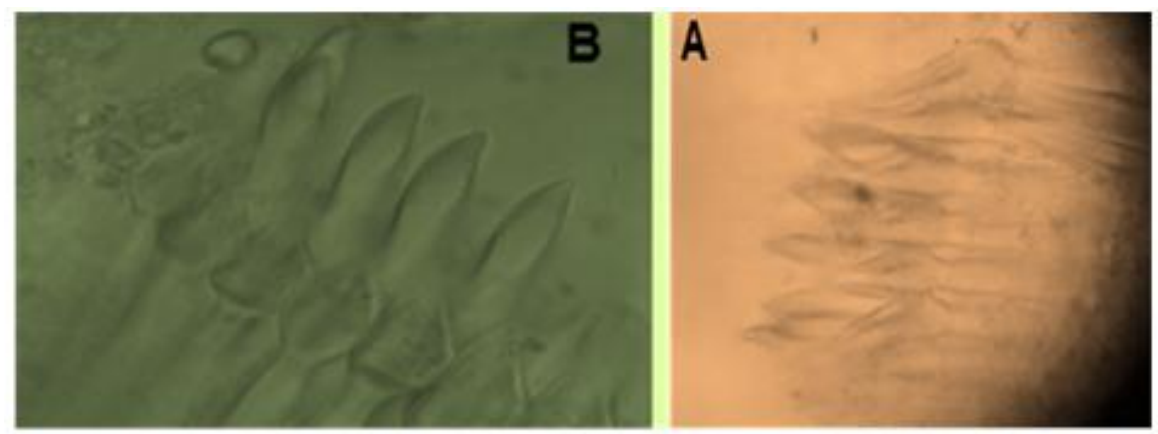

Fig. 2: Pseudopolydora paucibranchiata (A\&B) major setae of setiger number 5.

Boccardia polybranchia (Haswell 1885) (Figure3).

Polydora (Boccardia) polybranchia Fauvel, 1927: 58-59. Fig. 20 a-i; BenEliahu, 1976: 124.

Boccardia polybranchia Blake and Kudenov, 1978: 236-238, Fig.32 a; Blake, 1983: 248-249; 1996: 203; Day, 1967:463, Fig.18 a-h.

Material examined: It collcted from Gulf of Suez (st.6\&9) and El Max stations Distribution: Cosmopolitan species, it's origin is south Africa, so it is considered alien species may be comes through Suez Canal.
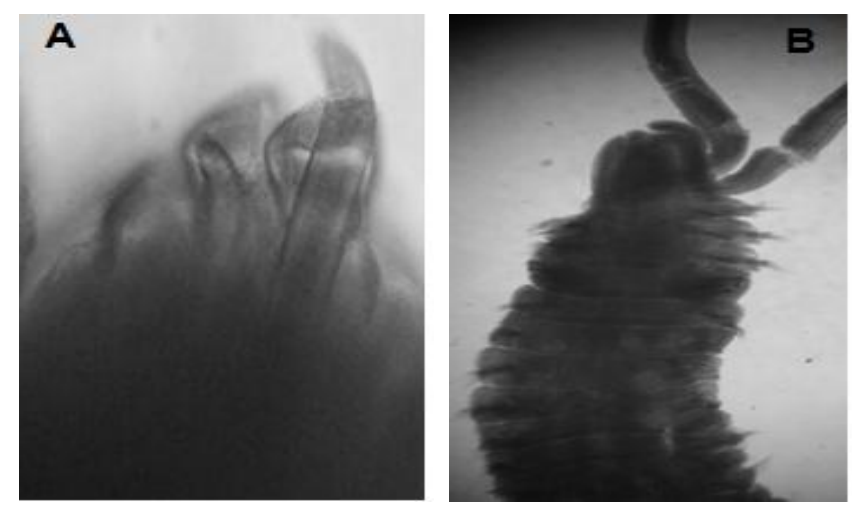

Fig. 3: Boccardia polybranchia (A) setiger 5 with major set, (B) Body with setiger five. 


\section{Dipolydora caeca (Oersted, 1843)}

Polydora caeca; Fauvel 1927: 52, fig. 18 a-k; Selim, 1978: 164-169, fig. 24 a-h; Abdelnany 2005:126, fig.77 a-d.

Material examined: It collected from Abu-Qir station with mud. It is considered dwelling muddy tubes. Found in sandy-mud bottom.

Distribution: Atlantic Ocean, Mediterranean Sea.

Polydora ciliata Annenkova, 1934 (Figure 4).

Polydora ciliata Hartman, 1959, p. 385; 1961: 98; Ben Eliahu, 1976; Fauvel , 1927; Abd Elnaby, 1999; 2005.

Material examined: It was collected from Abu-Qir and El Max stations. Mudy and sandy habitates respectivily.

Distribution: Atlantic Ocean, Mediterranean Sea.
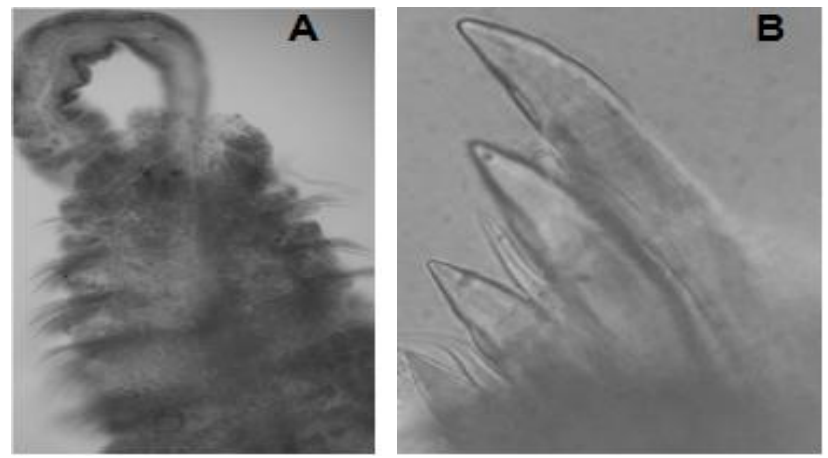

Fig. 4: Polydora ciliata, (A) Body with setiger five, (B) setiger 5 with major setae

Dipolydora giardi (Mesnil, 1893) (Figure 5).

Polydora giardi Fauvel, 1927 : 50-52, fig. 17 h-m; Ben Eliahu, 1976: 125; Blake and Kudenov, 1978: 252, fig. 38 i-k; Sato-Okoshi and Okoshi, 1997:484. Blake, 1996. Polydora anoculata Blake, 1971:25, fig. 15.

Material examined: It was collected from Abu-Qir Bay with mud.

Description: Incomplete specimen $6 \mathrm{~mm}$ long, for up to 50 setigers. Prostomium bified anteriorly. Caruncle extending to setiger 3; eyes absent. Setiger 1 with notoand neurosetae. Notopodia of setigers 2-4, 6, and the remaning anterior setigers with fascicles of unilimbate capillaries arranged in 2 rows, bidentate hooded hooks from setiger 7, beside 1-2 capillaries, with acute angle between main fang and secondary tooth and wide between main fang and shaft. Setiger 5 with curved row of heavy major spines alternate with pennon companion setae, major falcate spines with prominent large tooth on concave side. Branchiae from number 8 with small black spots in the region of branchiae.

Distribution: Mediterranean Sea and Pacific Ocean, Atlantic Ocean.
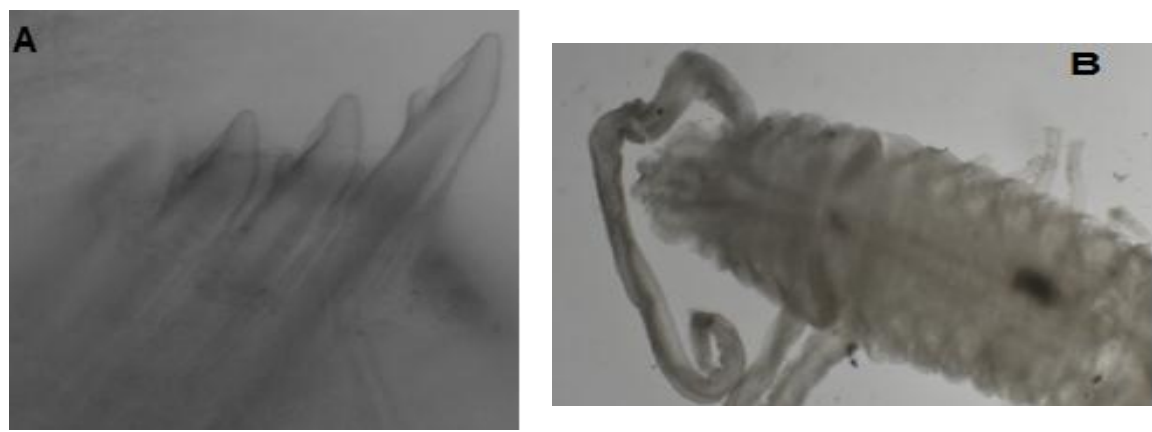

Fig. 5: Dipolydora giardi (A) setiger 5 with major setae, (B) Body with setiger five. 
Polydora cornuta Bosc, 1802 (Figure 6).

Polydora cornuta Sato-Okoshi, 2000: 445; Radashevsky, 2005: 6 figs. 1\&2.

Polydora (Polydora) cornuta: Hartmann-Schröder, 1996: 315-317, fig. 143.

Polydora ligni: Blake 1971, 5-6 figs.1-2; Sato-Okoshi and Okoshi,1997:487;

Dagli and Ergen 2008: 231-233, fig. 3 a-d.

Material examined: This species was collected from El-Max station.

Uncomplete specimen, with 25 segments, Prostomium anteriorly bifurcated.

Has prostomial antennae. Two pairs of black eyes, Low narrow caruncle extending to end of chaetiger 3. Palps long, with longitudinal groove, notochaetae absent from setiger one; short capillaries present in neuropodia. Parapodial lobes and postchaetal lamellae well developed on anterior chaetigers except chaetiger 5, gradually reducing on posterior chaetigers.

Chaetiger 5 with up to 8 major modified spines alternating with delicate companion chaetae, postchaetal lamellae lacking. Major spines and companion chaetae arranged in a slightly curved oblique double row. Major spines falcate, with lateral tooth and narrow thin subdistal longitudinal flange or keel positioned laterally on main fang distal to lateral tooth. Companion chaetae present, closely adhering to convex side of major falcate spines. With looke like feathers. Hooded hooks in neuropodia from chaetiger 7 replace with capilary setae, up to 15 in a vertical series, not accompanied by capillaries. Hooks bidentate, with shaft slightly curved having constriction on upper part. Branchiae from chaetiger 7. The species is here recorded for the first time for Egyptian waters.

Distribution

East, West and North America, Caribbean Sea, northern and southern Europe, Australia, China, Korea, Japan, India, Pacific coast of Russia.

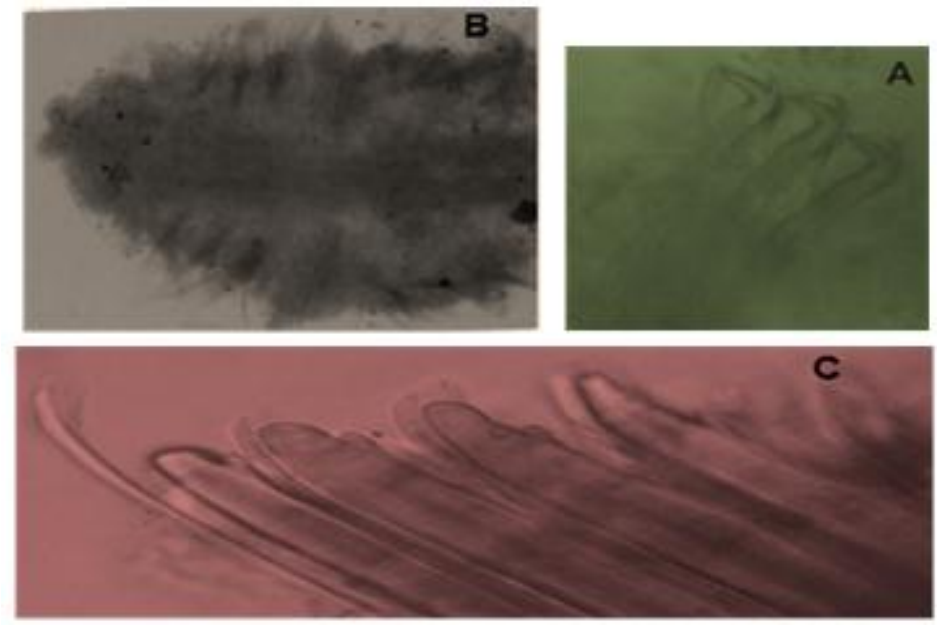

Fig. 6: Polydora cornuta, (A) hooks setae, (B) anterior part of body, (C) major setae of setiger five.

Polydora websteri Hartman in Loosanoff \& Engle, 1943(Fig. 7).

Blake \& Kudenov, 1978: 258, fig. 43 k-n; Blake 1971: 6-8, fig 3

Material examined: It was collected from Gulf of Suez (st.5).

The fragment consists of about 42 segments. The prostomium bifid at its anterior margin, four eyes. Carancle extend to segment two.The first segment without notopodial setae but neurosetae present. 2-4 segments are biramous with notosetae and neurosetae. The fifth with dorsal fascicle of heavy yellow hooks with companion pennoned setae, and a ventral fascicle of 5 or 6 pointed setae. The seventh setiger has pointed setae in both fascicles. Hooded hooks are present of the eighth setiger and 
continued posteriorly to the end. Branchiae, first present from the seventh setiger, are at first small but gradually enlarge. The heavy hooks of the fifth setiger number about 6 projecting in a fascicle. The hooded hooks in the middle of the body have 2 well developed teeth, the major one at a right angle to the shaft.

Remarks: P. websteri resembles P. ciliata (Johnston) (Fauvel, 1927), in some respects but the two differ in that the first has a prostomial caruncle that extends posteriorly to the end of the third setiger and the modified spines of the fifth setiger have a sheath around one side; in the second species the prostomial caruncle extends posteriorly to the second setiger and the modified spines have an acute tooth in the concave part of the spine, also agree with the speciemens of Blake (1971) in the presence of darke pigmentation. The species is here recorded for the first time for Egyptian waters.

Distribution: North Atlantic Ocean, Gulf of Mexico, Caribbean Sea.
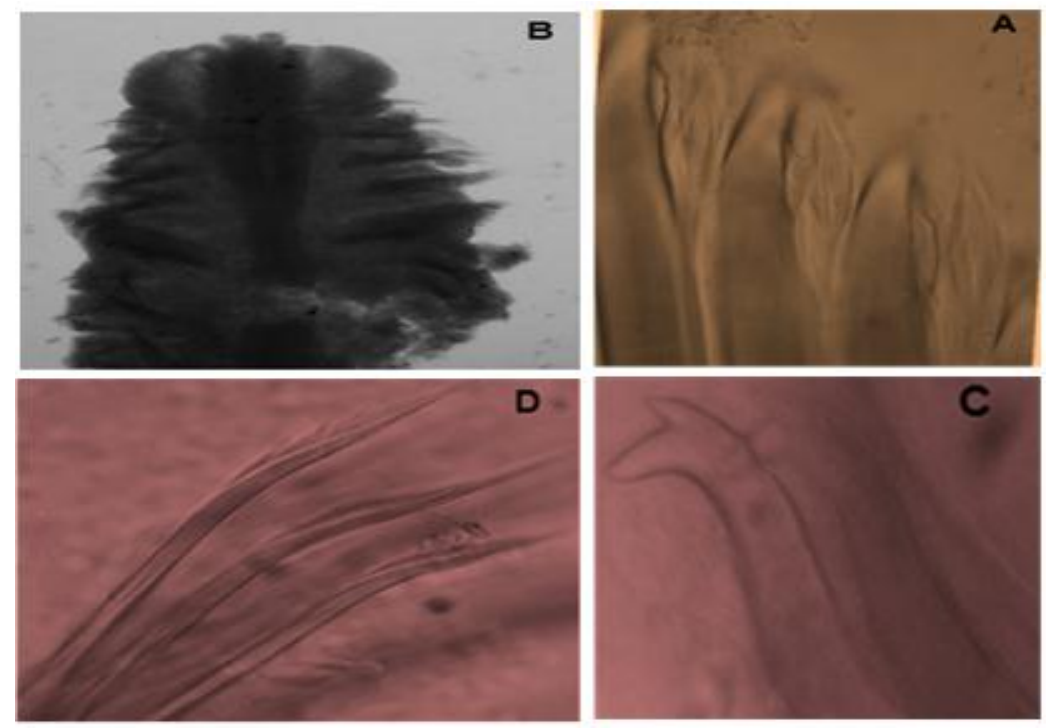

Fig. 7: Polydora websteri, (A) major setae of setiger five (B) anterior part of body, (C) hooks setae, (D) capillary setae.

Dipolydora socialis (Schmarda, 1861) (Figure 8).

Polydora caeca var magna Pettibone, 1967:11.

Polydora socialis: Hartman 1969:147; Blake, 1971:20-23, figs. 13-14.

Material examined: This species was collected from Abu-Qir Bay with mud.

Fragments, the largest one with 29 segments. Prostomium bifid; caruncle extending to setigers 5, four eyes. Palps long. Setiger 1 with capillary setae in notoand neuropodia. Setigers 2-4, 6, and subsequent setigers with 2 rows of capillary notosetae, setae of first row shorter, thicker than second; bidentate hooded hooks present from neuropodia of setiger 7, accompanied by 2-3 capillaries through anterior setigers, capillaries lost in middle setigers; hooks begin on setiger 7 with smooth curved shaft; Setiger 5 bearing dorsal bundle of geniculate modified spines alternating with smaller pennoned companion setae, and fascicle of winged neurosetae; modified spines falcate, with subterminal protuberance. Branchiae first present from setiger 2. The species recorded here for the first time for Egyptian Mediterranean waters.

Distribution: New South Wales, Victoria, Australia; the Sea of Japan, western Pacific; east and west coasts North America; Gulf of Mexico, Chile, Faulkland Islands. 


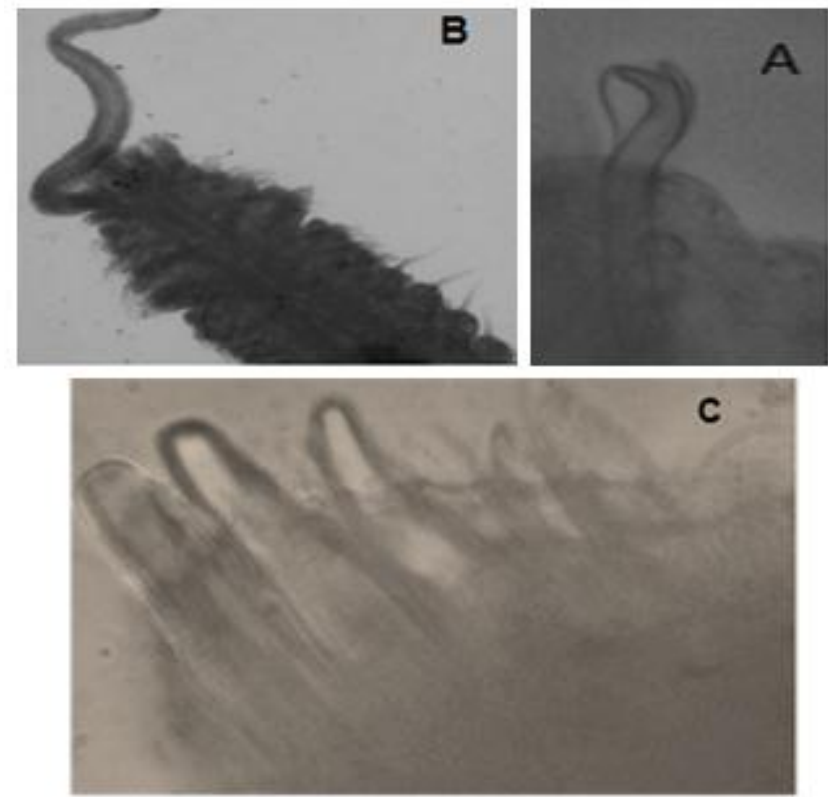

Fig. 8: Dipolydora socialis (A) hooks setae, (B ) anterior part of body, (C) special setae of setiger five.

Dipolydora armata (Langerhans, 1880) (Figure 9).

Polydora armata Fauvel, 1927:55-56, fig. 19a-e; Day, I967:466-468, fig. 18.2.i-j;

Hartmann-Schorder, 1979:134, figs. 299-302; Blake, 1983:258-260

Material examined. This species was collected from El Max station (sandy mud)

A small damaged specimen measures about $3 \mathrm{~mm}$. About19 segments. Notopodia of setiger 1 with 9 capillary setae; neuropodial capillaries more long. Notosetae and Neurosetae of setigers $2-4$, and 6 unilimbate capillaries in two rwos; bidentate hooded hooks from setiger 7(3in number), increase to 7. Setiger 5, with 3 falcate spine with subterminal semicircular cowl flange with fine spins on margin, in one row beside limbate capillary neurosetae, companion setae absent. Branchiae from setiger 7 continuing to setigers 13 . The species is here recorded for the first time for Egyptian Mediterranean waters.

Distribution: Dipolydora armata is a borer in calcareous substrates. The species is widespread in tropical and subtropical seas, and rare in temperate seas. It has been collected from coralline algal crusts (Blake and Evans, 1973).

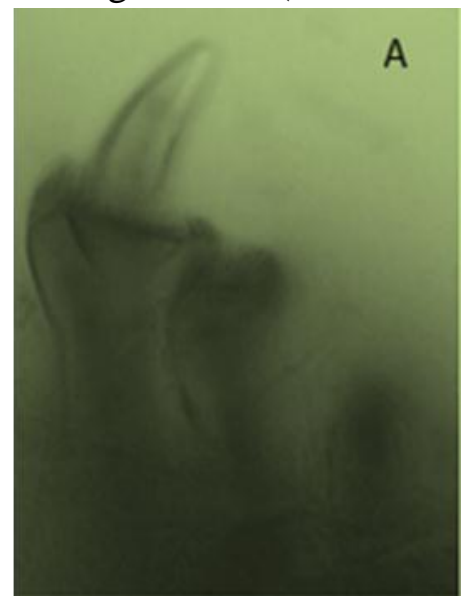

Fig. 9: Dipolydora armata, (A) special setae of setiger five.

Dipolydora protuberata (Blake \& Kudenov, 1978 (Figure 10).

Polydora protuberata Blake \& Kudenov, 1978: 250 fig.38 f-h. Blake, 1996: 189. 
Material examined: This species was collected from Gulf of Suez (st.6)

Fragment of one specimen, up to $4 \mathrm{~mm}$ long, for 44 segments. Prostomium distinctly bifid on anterior margin, caruncle extending to setigers 3 , eyes absent. Setiger 1 with capillary notosetae. Setigers $2-4,6$ and succeeding segments with unilimbate capillary neuro and notosetae. Neuropodial hooded hooks from setiger 7 , accompanied by capillary setae for a few segments. Setiger 5, with superior dorsal geneculate setae, a curved row of major spines and bilimbate companion setae beside ventral fascicle of unilimbate capillaries; major spines simple falcate, with a large subterminal protuberance. Branchiae from setiger 8 . The species is here recorded for the first time for Egyptian waters.

Distribution: Victoria, Port Phillip Bay, Australia.

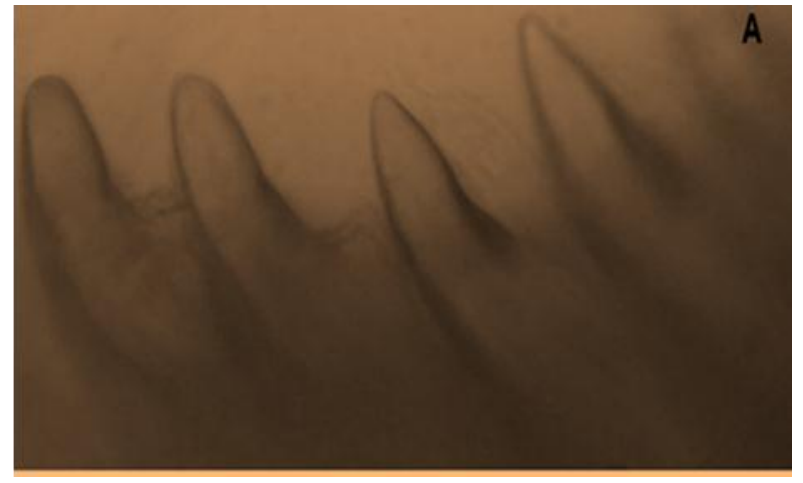

Fig. 10: Dipolydora protuberata, (A) special setae of setiger five

\section{DISCUSSION}

Some polyorid species have boring behavior into calcareous substrate, forming boring species such as all polydorides with one row of major spines on segement number five. The present study reveals that the habitat of the polydorid species and the shape of the major spines are important to detect if it's type are boring species such as Dipolydora armata, D . socialis, Polydora ciliata, D. giardi, P. websteri, D. caeca ( Simon\& Sato-Okoshi, 2015), or dwelling (non- boring species) such as Boccardia polybranchia, Pseudopolydora paucibranchiata, Polydora cornuta and Polydora protuberata, the structures and habitat of them are suitable for non-boring activity. This agrees with selim (2006), abd Elnaby (2005) and Sato- Okoshi (2000) who reported and confirmed the relation between the shape of the major spines and boring and non boring activity. Boring species have falcate heavy spines with accessory tooth or flange, because it may be suitable for borers to use them to claw calcareous particles come as a result from burrow activity, except $P$. cornuta it is reported as nonboring type, but it has falcate setae which means it has borer activity. While Radashevsky (2000) disagree with this fonomena, he mentioned that no structural adaptation differantiat between the boring and non-boring activity. SatoOkoshi and Okoshi (1997), they mentioned that the appearance of boring and nonboring activity depend on the type of habitat. Dipolydora socialis reported as borer and non-borer species (Blake, 1996 and Sato-Okoshi, 1997). This non-borring species have behavioural and morphological characteristics of borers such as slow branchial crawler, weak palp, narrow palpe blood vessels (Sato-Okoshi, 2000). D.giardi was reported to have been extracted from shells, bryzoans, corallina algae and recently from wild subtidal mollusks (Sato-Okoshi et al., 2008). 
Introductions of spionid polychaetes are reported from many areas around the world via ballast water and aquacultural products (Carlton and Geller 1993; Blake 1996; Rohner et. al., 1996; Bailey Brock, 2000). Also invasie species which cause, replacing the native species, extinction, deletation are occure due to human activity which affect on the biodiversity of fresh and marine biota (Carlton, 2009; Radoshevsky\& Selifonova, 2013). The most polydorid species repoted here are alien species such as B. polybranchia, D.armata, D.giardi, D. socialis, $P$. ciliata, $P$. cornuta, P. websteri (Çinar, 2013). Perhaps as a result of not continouse publishing research on polychaetes, A large number of polychaetes have been classified but still not published, so this is an attempt to start spreading more to identify the Egyptian polychaetes and focusing on alien species in particular.

\section{REFERENCES}

Abd Elnaby, F. A. (2005). Systematic and environmental studies on polychaetes from Alexandria marine waters. Ph.D. Thesis. Faculty of Scinece Suez Canal University, 330pp.

Abe H.; Takeuchi T.; Taru M.; Sato-Okoshi W. and Okoshi K. (2019). Habitat availability determines distribution patterns of spionid polychaete (Annelida spionidae) around Tokyo Bay . Mar. Biodiv. Rec.,pp.1-12.

Bailey-Brock, J. H. (1990). Polydora nuchalis (Polychaeta: Spionidae), a new Hawaiian record from aquaculture ponds. Pac. Sci., 44:81-87.

Bailey-Brock, J. H. (2000). A New Record of the Polychaete Boccardia proboscidea (Family Spionidae), Imported to Hawai'i with Oysters. Pac. Sci., 54 (1): 27-30.

Carlton, J.T. (2009). Deep invasion ecology and the assembly of communities in historical time. p. 13-56. In: Biological Invasions in Marine Ecosystems. Ecological Studies 204. Rilov,G. \& Crooks, J. A. (Eds). Springer, Berlin Heidelberg.

Carlton, J. T. and Geller, J. B. (1993). Ecological roulette: The global transport of nonindigenous marine organisms. Sci. (Wash., D.C.), 261:78-82.

Çinar, M. (2013). Alien polychaete species worldwide: Current status and their impacts. J. Mar. Biol. Assoc. UK, 93(5):1257-1278.

Hartmann, O. (1969). Atlas of the Sedentariate Polychaetous Annelids from California, Allan Hancock Foundation, Univ. of South. Calif., 812pp.

Ben-Eliahu, M. N. (1976). Polychaete cryptofauna from rims of similar intertidal: vermetid reefs on the Mediterranean coasts of Israel and Gulf of Elat Sedentaria, Isr. J. Zool., 25: 121-155.

Blake, J. and Evans, J. (1972). Polydora and related genera as borers in mollusk shells and other calcareous substrates (Polychaeta: Spionidae). Veliger, 15: 235-249.

Blake, J. (1983). Polychaetes of the family Spionidae frome South America, Antarctica and adjacent seas and islands. Biology of the Antarctic Seas 14.Antrtic Res. Ser., 39: 205-288.

Blake, J. (1971). Revision of the genus Polydora from the east coast of North America (Polychaeta: Spionidae) Smith. Contrib. Zool., 75: 1-32.

Blake, J. (1996). Family Spionidae Grube, 1850. pages 81-223. IN: Blake, James A.; Hilbig, Brigitte; and Scott, Paul H. Taxonomic Atlas of the Benthic Fauna of the Santa Maria Basin and Western Santa Barbara Channel. 6 - The Annelida Part 3. Polychaeta: Orbiniidae to Cossuridae. Santa Barbara Museum of Natural History. Santa Barbara. 
Blake, J. and Kudenov, J. (1978). The Spionidae (Polychaeta) from Southeastern Australia and adjacent areas with a revision of the genera. Memo. Nat. Mus. of Vict., 39: 171-280.

Çinar, M. E. (2013). Alien polychaete species worldwide: current status and their impacts. J. Mar. Biol Ass. UK, 93:1257-1278.

Dagli, E. and Ergen, Z. (2008). First record of polydora cornuta Bosc, 1802 (Polychaeta: Spionidae) from the Sea of Marmara, Turkey Basin. Aquat. Invas., 3 (2): 231-233.

Day, J. (1967). Polychaetes of southern Africa, Part 1: Errantia, Brit. Mus Nat. Hist.), London, $878 \mathrm{pp}$.

Fauvel, P. (1927). Polych`etes s'edentaires addenda aux errantes, archiann’elides myzostomaires, Faune France, Ed. le Chevalier Paris, 16: 1-412.

Hamdy, R. (2008). Ecological studies on benthic polychaetes along Alexandria coast Mr. Sc. thesis, Alex. Univ., 214 pp.

Hartman, O. (1943). Description of Polydora websteri.In:Loosanoff, V. L. \& J. B. Engle, Polydora in oysters suspended in the water. Biol. Bull., 85:69-78.

Hartman, O. (1959). Catalogue of the Polychaetous Annelids of the World. Parts 1 and 2. Allan Hancock Foundation Occasional Paper, 23: 1-628.

Hartmann, O. (1969). Atlas of the Sedentariate Polychaetous Annelids from California, Allan Hancock Foundation, University of Southern California, 812pp.

Hartmann-Schröder, G. (1996). Annelida, Borstenwürmer, Polychaeta [Annelida, bristleworms, Polychaeta]. $2^{\text {nd }}$ revised ed. The fauna of Germany and adjacent seas with their characteristics and ecology, 58. Gustav Fischer: Jena, Germany. ISBN 3-437-35038-2. 648 pp.

Hartmann-Schröder, G. (1979). Teil 2. Die Polychaeten der tropischen. Nordwestküste Australiens (Zwischen Port Samson in Norden und Port Hedland in Süden). Mitt. aus dem Hamburg. Zool. Mus. und Inst., 76: 75-218.

Imajima, M. \& Hartman, O. (1964). The polychaetous annelids of Japan. Occasional Papers of the Allan Hancock Foundation, 26 (1-2): 1-452.

Katsanevakis, S.; Waluentinus, I.; Zenetos, A.; Leppakoski, E.; Cinar, M.; Ozlurk, B.; Grabowski, M.; Golani, D. and Cardoso, A. (2014). Impacts of in vasive alien marine species on ecosystem services and biodiversity: a Pan-European review Aquat invas., 9: 391-423.

Mack, R.; Simberloff, D.; Lonsdale, W.; Evans, H.; Clout, M. and Bazzaz, F. (2000). Biotic invations: causes, epidemiologyglobal consequences, and control. Ecol. Appl., 10: 689-710.

Miura, O. (2007). Molecular genetic approaches to elucidate the ecological and evolutionary issues associated with biological invasions. Ecol. Res., 22: 876-883.

Mona, M. (1991). Contributios to the knowledge of family Spionidae (Annelida, Polychaeta) in the northern part of Suez Canal with redescriotion of newly recorded species. Bull. Act. Sci.. Zagazig Univ., 13 (2): 500-518.

Mostafa, M. S. (1992). Surveillance and ecological studies on the polychaetes in Lake Timsah (Suez Canal, Egypt). Ph. D. Thesis Zagazig Univ., 249pp.

Okuda, S. (1937). Spioniform polychaetes from Japan. J. Fac. of Sci. Hokkaido Univ. Series 6, Zool., 5(3): 217-254.

Pettibone, M. H. (1967). Marine polychaete worms of the New England region, Families Aphroditidae through Trochochaetidae. U.S. Nat. Mus. Bull., 227(1):1356. 
Radashevsky, V. I. (1993). Revision of the genus Polydora and related genera from the north west Pacific (Polychaeta: Spionidae). Publications of the Seto Mar. Biol. Laboratory, 36(1/2): 1-6.

Radashevsky, V. I . (2005). On adult and larval morphology of Polydora cornuta Bosc, 1802 (Annelida: Spionidae). Zootaxa, 1064: 1-24.

Radashevsky, V. I.; Lana, P. C. and Nalesso, R. C. (2006). Morphology and biology of Polydora species (Polychaeta: Spionidae boring into oyster shells in South America, with the description of a new species. Zootaxa, 1353: 1-37.

Radashevsky, V. I. and Pankova, V. (2006). The morphology of two sibling sympatric Polydora species (Polydora: Spionidae) from the Sea of Japan. J. Mar. Biol. Ass. UK, 86: 245-252.

Radashevsky, V. I. and Selifonov, A. (2013). Records of Polydora cornuta and Streblospio gynobranchiata (Annelida, Spionidae) from the Black Sea. Med. Mar. Sci., 14(2): 261-269.

Rohner, M.; Bastrop, R. and Jiirss, K. (1996). Colonization of Europe by two American genetic types or species of the genus Marenzelleria (Polychaeta: Spionidae). An electrophoretic analysis of allozymes. Mar. BioI. (Berl.), 127:277-287.

Sato-Okoshi, W. (1999). Polydorid species (Polychaeta: Spionidaein Japan, with descriptions of morphology, ecology and burrow structure. 1. Boring species. J Mar Bio logy and burrow structure. 1. Boring species. J Mar Biol. Ass. UK, 79: 831-848.

Sato-Okoshi, W. (2000). Polydorid species (Polychaeta: Spionidaein Japan, with ecology, descriptions of morphology 1 . boring and burrow structure. 2. Nonboring species. J. Mar. Biol. Ass. UK, 80: 443-456.

Sato-Okoshi, W. and Abe, H. (2012). Morphological and molecular sequence analysis of the harmful shell boring species of Polydora (Polychaeta: Spionidae) from Japan and Australia Aquacul., 40-47.

Sato-Okoshi, W. and Abe, H. (2013). Morphology and molecular analysis of the $18 \mathrm{~S}$ rRNA gene of oyster shell borers, Polydora species (Polychaeta: Spionidae), from Japan and Australia. J. Mar. Biol. Ass. of UK, 93: 1279-1286.

Sato-Okoshi, W. and Okoshi, K. (1997). Survey of the genera Polydora, Boccardiell and Boccardia (Spionidae, Polychaeta) in Barkley sound (Vancouver- Island). Bull. Mar. Sci., 60(2): 482-493.

Sato-Okoshi, W.; Okoshi, K, K.; Kim, B. and Hong, J. S. (2012). Polydorid species (Polychaeta: Spionidae) associated with commercially important mollusk shells in Korean waters. Aquacul., 82-90.

Sato-Okoshi, W.; Okoshi, K. and Shaw, J. (2008). Polydorid species (Polychaeta: Spionidae) in south-western Australian waters with special reference to Polydora uncinata and Boccardia knoxi. J. Mar. Biol. Ass. UK, 88: 491-501.

Sato-Okoshi, W.; Sugawara, Y. and Nomura, T. (1990). Reproduction of the boring polychaete Polydora variegata inhabiting scallop in Abashiri Bay, North Japan. Mar. Biol., 104: 61-66.

Selim, S. A. (1978). Systematic and distributional studies of polychaetes in the Eastern Harbour, Alexandria. M. Sc. Thesis. Alexandria Univ., 200 pp.

Selim, S. A .(1997). New records of two benthic polychaetes from Egyptian Mediterranean waters. J. Egtyupt. Ger. Soc. Zool., 22 (D): 29-39.

Selim, S. A. (2006). Newly recorded spionid species (Polychaeta) from the Egyptian waters, with special reference to Polydorids habitats. Egypt. J. Aquat. Biol.\& Fish., 10 (1): 191-210. 
Simon, C. A.; Bentley, M. G. and Caldwell, G. S . (2010). 2,4-decadienal exploring a novel approach for the control of polychaete pests on cultured abalone. Aquac., 310: $52-60$.

Simon, C. A. and Sato-Okoshi, W. (2015). Polydorid polychaetes on farrmed molluscs, distribution, spread, actors contributing to their success. Aquac. Environ. Interact, 17: 147-166.

Teramoto, W. ; Sato-Okoshi, W.; Abe, H.; Nishitani, G. and Endo, Y. (2013). Morphology, 18S rRNA gene sequence, and life history of a new Polydora species (Polychaeta, Spionidae) from northeastern Japan. Aquat. Biol., 18: 3145 . 